\title{
Inferring Population History of Tiger Beetle Species of Sri Lanka using Mitochondrial DNA Sequences
}

\author{
Chandima D. Dangalle ${ }^{1 *}$, Nirmalie Pallewatta ${ }^{2}$ and Alfried P. Vogler ${ }^{3}$ \\ ${ }^{1,2}$ Department of Zoology, Faculty of Science, University of Colombo, Colombo 03, Sri Lanka. \\ ${ }^{3}$ Department of Entomology, Natural History Museum, Cromwell Road, London, SW7 5BD, \\ United Kingdom. \\ Accepted July 20, 2014
}

\begin{abstract}
Tiger beetles are an important insect group in Sri Lanka due to their high species richness and endemicity. The present study investigated the distribution of tiger beetle species populations in Sri Lanka and history of species populations. Distribution was studied by conducting extensive field work that recorded the locations, habitat types and habitat preferences of tiger beetle species. DNA sequence data of three mitochondrial genes were used to study the history of species populations. The genetic indices: haplotype diversity, nucleotide diversity and Tajima's D statistic were computed using DNA sequence data. The study revealed the distribution of ten tiger beetle species of Sri Lanka and their habitat types. According to genetic indices the tiger beetles of Sri Lanka are single species populations that consist of subpopulations distributed in locations that are not separated by major geographical barriers. There is a high probability that all species are experiencing population expansion after either habitat displacement by other tiger beetle species, expansion of suitable new habitats and natural disasters.
\end{abstract}

Keywords: distribution, genetic indices, population expansion

\section{INTRODUCTION}

Sri Lanka is an island with unique assemblages of plant and animal communities and endemic species, and therefore recognized as a biodiversity hotspot of global and national importance (Bossuyt et al., 2004; Pethiyagoda, 2005). The insect fauna of Sri Lanka represents a large part of it's biodiversity and amounts to $53 \%$ of the total species diversity of the island (Wijesekara and Wijesinghe, 2003). However, insects are rarely included in accounts of biodiversity in Sri Lanka, and even when they are included, only a few well known groups such as the butterflies, dragonflies, mayflies, mosquitoes, carabid and blister beetles are featured in such analyses. The reason for this is the lack of information on Sri Lankan insects due to the inadequacy of studies and the lack of an active national insect study and curation programme.

Tiger beetles (Coleoptera, Cicindelidae) have been reported from Sri Lanka since 1860 (Tennent, 1860) and existing literature (Horn, 1904; Fowler, 1912; Naviaux, 1984; Acciavatti and Pearson, 1989), and collections available at the National Museum of Colombo, Sri Lanka and British Natural History Museum of London have documented 59 species from the island. Sixty-six percent of these documented species are endemic and Sri Lanka has been ranked amongst the top thirty countries of the world with the highest rates of endemism for tiger beetles and as an area of high species richness for this group (Cassola and Pearson, 2000). However, studies on this important insect group tends to be extremely inadequate and information on current species diversity, geographical distributions of species and populations, evolutionary origins and history of populations and species are unknown.

At present, the ability to obtain DNA sequence information from individuals is used to identify and revise species, and access to increasingly powerful computers with sophisticated software has facilitated studies on the demographic history and evolutionary relationships of species. Thus, certain molecular studies on identifying and resolving phylogenetic postion of fish (Dammannagoda et al., 2011; Nguyen et al., 2008), amphibians (Delorme et al., 2004; Hewitt, 2004), birds (Silva et al., 2009) and mammals (Fernando et al., 2000; Samaraweera et al., 2011) has been carried out in Sri Lanka. However, molecular studies on the insects of Sri Lanka are rare with the exception of a few carried out on insect vectors responsible for mosquito-borne diseases (Hemingway et al., 1998; Surendran et al., 2006)

*Corresponding author's email: cddangalle@gmail.com 
Therefore, a molecular study was conducted by us on the tiger beetles of Sri Lanka using information of three gene regions of the mitochondrial DNA genome. The study led to the initiation of construction of a sequence database for the tiger beetles of Sri Lanka from which sequence information was submitted to Genbank for future studies. Further, geographical distributions of tiger beetle species and their populations were investigated and the most basal haplotype of each species was derived. Haplotype diversities, nucleotide diversities and Tajima's D statistic was used to address certain aspects of the evolutionary history of species populations.

\section{MATERIALS AND METHODS}

Sampling of Taxa, Collection and Identification Ninety-four locations in Sri Lanka were surveyed for tiger beetles during 2002 to 2006 . When tiger beetles were encountered, a sample of 1 to 7 beetles were collected from each location using a standard insect net and transferred into a vial containing $96 \%$ ethyl alcohol. Collected specimens were morphologically examined and identified using taxonomic keys for the Cicindela of the Indian subcontinent (Acciavatti and Pearson, 1989), and descriptions of Horn (1904) and Fowler (1912). Identifications were further confirmed by comparisons with reference specimens at the Department of National Museums, Sri Lanka and the British Natural History Museum, London, United Kingdom. Taxonomic names of species with the present nomenclatural changes are based on Wiesner 1992, except for the use of Calomera instead of Lophyridia which is based on Lorenz, 1998.

\section{Molecular Biological Procedures}

DNA was extracted from whole beetles using the Qiagen DNeasy Tissue Extraction kit (Qiagen Inc., Valencia, California) which yields DNA fragments of length $50,000 \mathrm{~kb}$ and shorter. Three regions of the mitochondrial genome, coding for Cytochrome Oxidase I (COI), 774 bp; Cytochrome b (Cyt B), $356 \mathrm{bp}$ and 16SrRNA, $827 \mathrm{bp}$ were polymerase chain reaction (PCR) amplified. The fragments were amplified using the following primers: M202 (5'-CAACATTTATTTTGATTTTTTGG-3') and M70 (5'-TCCATTGCACTAATCTGCCATATTA3') for $\mathrm{CO} 1$ region, $\mathrm{CB} 3$ (5'GAGGAGCAACTGTAATTACTAA-3') and CB4 (5'-ATTCAACCTGAATGATACTTTTCTTTT3') for CytB region, M14 (5'-CGCCTGTTTATC3') and M223 (5'-GGTCCCTTACGAATTTG AATATATCCT-3') for $16 \mathrm{SrRNA}$ region. PCR conditions were as follows: $2 \mathrm{~min}$. at $94^{\circ} \mathrm{C}$ followed by $35-40$ cycles of denaturation at $94^{\circ} \mathrm{C}$ for $30 \mathrm{~s}$, annealing at $40-45^{\circ} \mathrm{C}$ for $30 \mathrm{~s}$ and extension at $72^{\circ} \mathrm{C}$ for $1 \mathrm{~min}$., with a final extension step at $72^{\circ} \mathrm{C}$ for $10 \mathrm{~min}$. PCR products were purified using the Millipore Multiscreen 96-well plates (Millipore, Billerica) and were sequenced in both directions using ABI PRISMTM 3700 DNA Analyser (Applied Biosystems).

\section{Genetic Diversity of Tiger Beetle populations}

A total of 96 tiger beetle sequences from Sri Lanka were used for the molecular analyses. Sequences were manually edited and data from all three regions of the mitochondrial genome were combined and aligned using ClustalW of MEGA version 5.05.

Genetic diversity was estimated for seven tiger beetle species that consisted of two or more geographically distinct populations. Genetic diversity within the populations of tiger beetle species were estimated by computing haplotype diversity (Hd) and nucleotide diversity (Pi). Haplotype diversity represents the probability that two randomly sampled alleles are different, while nucleotide diversity is defined as the average number of nucleotide differences per site in pairwise comparisons among DNA sequences. Both parameters were calculated using the program DnaSP version 4.50 (Rozas et al., 2003). Number of polymorphic sites, number of haplotypes, number of single-copy haplotypes (singletons) and Tajima's D statistic were also calculated using DnaSP. Tajima's D statistic is a widely used test of neutrality in population genetics and was tested with 10,000 coalescent simulations in DnaSP. Species generating negative Tajima's D values were further analysed to determine whether the negative signature was due to population expansion or positive selection, and Tajima's D was calculated separately for synonymous sites and non-synonymous sites. For calculation of Tajima's D [Syn] and Tajima's D [Non-Syn], separate gene regions for CO1, CytB and $16 \mathrm{~S}$ of the mitochondrial genome was used. Significant negative values for Tajima's D [Syn] were considered to illustrate population expansion in species. To describe the phylogeographic structure and genetic relationships between haplotypes, haplotype networks were computed using HapStar version 0.5. The networks were subsequently drawn by hand.

\section{RESULTS}

Sampling of Taxa, Collection and Identification Ten species of tiger beetles were recorded from 37 locations of Sri Lanka in coastal, reservoir, riverine and urban habitats (Fig. 1 and Table 1). Of these, 
two species, Cylindera (Ifasina) waterhousei Horn and Cylindera (Ifasina) willeyi Horn are endemic to Sri Lanka.

Seven tiger beetle species, Lophyra (Lophyra) catena Fabricius, Myriochila (Monelica) fastidiosa Dejean, Calomera angulata Fabricius, Hypaetha biramosa Fabricius, Cylindera (Ifasina) labioaenea Horn, Cylindera (Ifasina) waterhousei Horn and Cylindera (Ifasina) willeyi Horn consisted of populations distributed in two or more locations while three tiger beetle species, Cylindera (Oligoma) paradoxa Horn, Cylindera (Oligoma) lacunosa Putzeys and Calomera cardoni Fleutiaux were confined to populations in a single location (Table 1).

\section{Basic sequence information}

The data matrix included 96 newly sequenced tiger beetle specimens from Sri Lanka. COI fragment was amplified and sequenced successfully from all specimens, $\mathrm{CytB}$ fragment was amplified and sequenced successfully from 93 specimens and 16SrRNA was amplified and sequenced successfully from 85 specimens. All sequences were submitted to Genbank (Appendix 1).

\section{Genetic Diversity of Tiger Beetle populations}

Genetic diversity was calculated for seven tiger beetle species using aligned mitochondrial DNA sequences (Table 2). The seven tiger beetle species that consisted of two or more populations displayed high haplotype diversity (Hd) ranging between 0.6667 for Cylindera (Ifasina) waterhousei and 1.000 for Myriochila (Monelica) fastidiosa. In contrast, nucleotide diversity was relatively low ranging between 0.00131 for Cylindera (Ifasina) waterhousei and 0.01173 for Myriochila (Monelica) fastidiosa (Table 2). High haplotype diversity was due to the large number of single-copy mtDNA haplotypes or singletons. The number of singletons increased as the total number of haplotypes increased (Fig. 2).

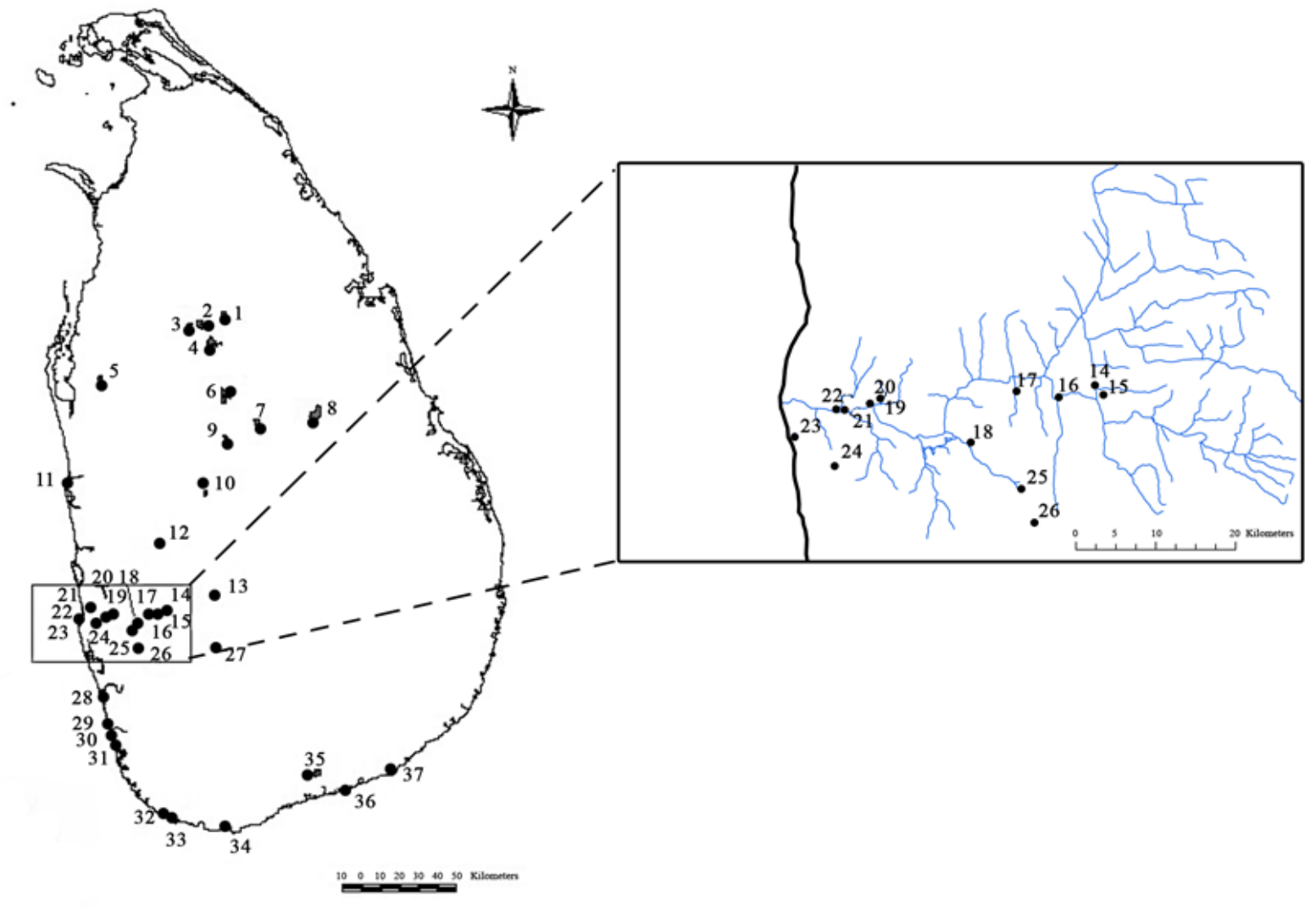

Figure 1. Locations of Sri Lanka from which tiger beetles were recorded and collected 
Table 1. Tiger beetle species collected from study sites of Sri Lanka

\begin{tabular}{|c|c|c|}
\hline Species & $\begin{array}{l}\text { Sampled location (location number in } \\
\text { the Fig } 1 \text { is given within brackets) }\end{array}$ & $\begin{array}{l}\text { Number of individuals } \\
\text { collected }\end{array}$ \\
\hline Lophyra catena & $\begin{array}{l}\text { Devahuwa wewa, Dambulla (9) } \\
\text { Chilaw coast, Chilaw (11) } \\
\text { National Museum Garden, Colombo (23) } \\
\text { Katukurunda coast, Katukurunda (28) } \\
\text { Aluthgama coast, Aluthgama (29) }\end{array}$ & $\begin{array}{l}01 \\
04 \\
02 \\
04 \\
02\end{array}$ \\
\hline Myriochila (Monelica) fastidiosa & $\begin{array}{l}\text { Nachchaduwa wewa, Anuradhapura(4) } \\
\text { Tabbowa wewa, Karuwalagaswewa (5) } \\
\text { Kandalama wewa, Dambulla (6) }\end{array}$ & $\begin{array}{l}03 \\
03 \\
02\end{array}$ \\
\hline Cylindera (Ifasina) labioaenea & $\begin{array}{l}\text { Maha Oya Falls, Dehi Ovita (15) } \\
\text { Seethavaka river, Thalduwa (16) } \\
\text { Asvathu Oya, Avissawella (17) } \\
\text { Heen Ela, Waga (18) } \\
\text { Kelani river, Malwana (19) } \\
\text { Kelani river, Kirielamulla (20) } \\
\text { Kelani river, Kaduwela (21) } \\
\text { Home garden, Angoda (24) } \\
\text { Wak Oya, Thummodara (25) }\end{array}$ & $\begin{array}{l}03 \\
01 \\
04 \\
01 \\
03 \\
02 \\
02 \\
01 \\
01\end{array}$ \\
\hline Cylindera (Ifasina) willeyi & $\begin{array}{l}\text { Maha Oya, Dehi Owita (14) } \\
\text { Water canal, Handapangoda (26) }\end{array}$ & $\begin{array}{l}01 \\
07\end{array}$ \\
\hline Cylindera (Ifasina) waterhousei & $\begin{array}{l}\text { Water canal, Handapangoda (26) } \\
\text { Bopath Ella, Ratnapura (27) }\end{array}$ & $\begin{array}{l}02 \\
05\end{array}$ \\
\hline Cylindera (Oligoma) paradoxa & National Museum Garden, Colombo (23) & 04 \\
\hline Cylindera (Oligoma) lacunosa & Devahuwa wewa, Dambulla (9) & 01 \\
\hline Calomera angulata & $\begin{array}{l}\text { Mahakanadarawa wewa, Anuradhapura (1) } \\
\text { Thisa wewa, Anuradhapura (3) } \\
\text { Nachchaduwa wewa, Anuradhapura (4) } \\
\text { Tabbowa wewa, Karuwalagaswewa (5) } \\
\text { Kala wewa, Anuradhapura (6) } \\
\text { Kandalama wewa, Dambulla (7) } \\
\text { Parakrama Samudra, Polonnaruwa (8) } \\
\text { Devahuwa wewa, Dambulla (9) } \\
\text { Batalagoda wewa, Ibbagamuwa (10) } \\
\text { Ma Oya, Alawwa (12) }\end{array}$ & $\begin{array}{l}03 \\
05 \\
01 \\
02 \\
03 \\
02 \\
03 \\
03 \\
03 \\
01\end{array}$ \\
\hline Calomera cardoni & Ma Oya, Alawwa (12) & 03 \\
\hline Hypaetha biramosa & $\begin{array}{l}\text { Kosgoda beach, Kosgoda (31) } \\
\text { Matara beach, Matara (34) } \\
\text { Habaraduwa beach, Habaraduwa (33) }\end{array}$ & $\begin{array}{l}03 \\
03 \\
02\end{array}$ \\
\hline
\end{tabular}




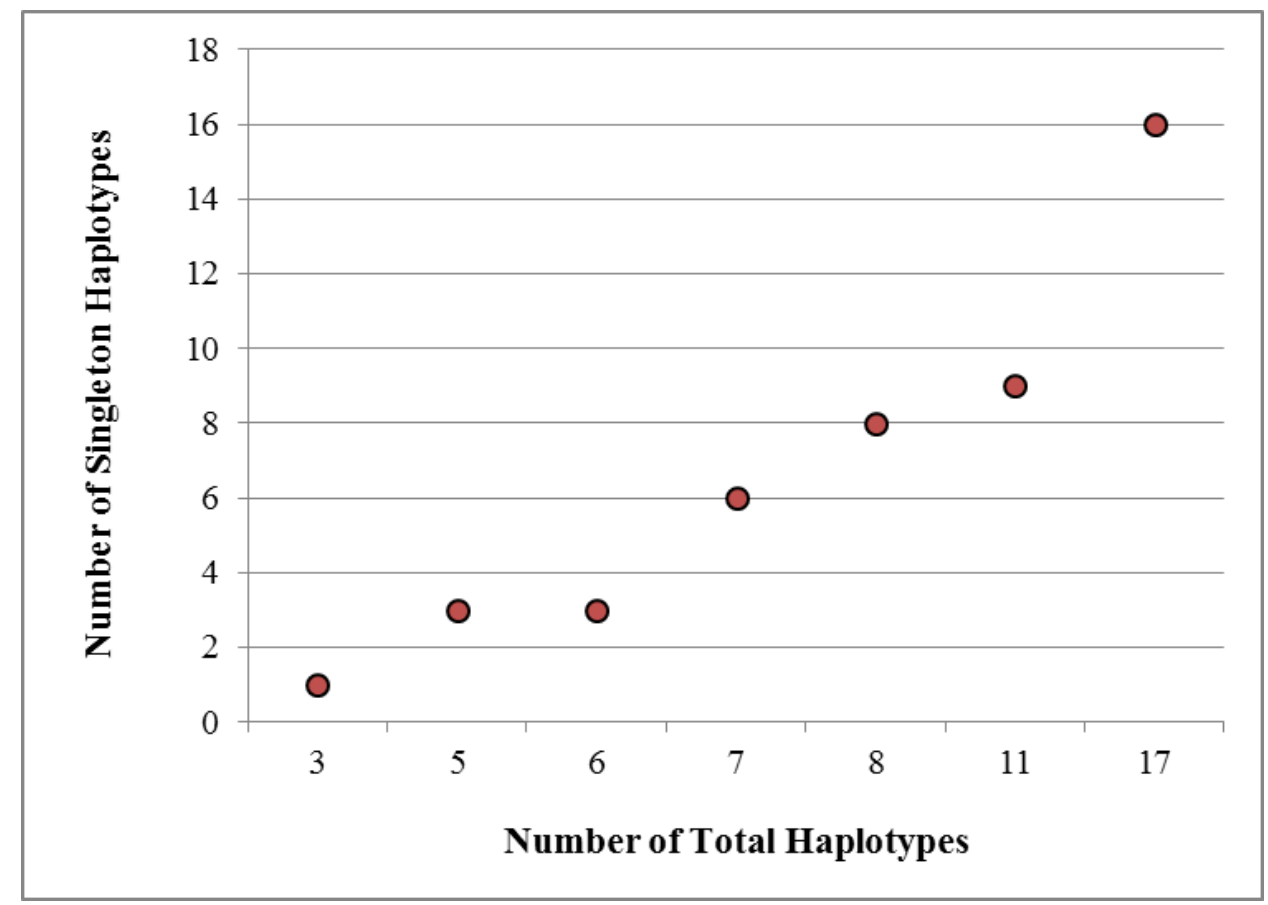

Figure 2. Singleton haplotypes versus total haplotypes discovered from population sampling of Tiger Beetles

The seven haplotype networks (Fig. 3) constructed for the tiger beetle species clearly reflected the results of the diversity indices. All geographical populations of Myriochila (Monelica) fastidiosa consisted of unique haplotypes or singletons (Fig. 3B), whereas, all other species possessed a haplotype shared with at least one other geographical population or was a doubleton.

The haplotype networks for individual species revealed no evidence of phylogeographic structure, and for all species with the exception of Myriochila (Monelica) fastidiosa common haplotypes were found that were not restricted geographically (Fig. 3).

Tajima's D statistic was negative for the populations of four tiger beetle species, Lophyra (Lophyra) catena, Myriochila (Monelica) fastidiosa, Cylindera (Ifasina) labioaenea and Calomera angulata. However, the negative values were not significant under coalescent simulations (Table 2). Tajima's D value calculated for the separate genes, CO1, CytB, 16SrRNA, were also negative and Tajima's D value for synonymous sites were negative with the exception of the positive value for 16SrRNA gene of Cylindera (Ifasina) labioaenea. When considering Tajima's $\mathrm{D}$ ratio, all species illustrated a combination of ratios less than 1.0 and more than 1.0 for the different gene regions (Table 3). Tajima's D statistic was positive for the populations of three species, Hypaetha biramosa, Cylindera (Ifasina) willeyi and Cylindera (Ifasina) waterhousei (Table 2).

\section{DISCUSSION}

When considering the distribution of tiger beetle species populations, we found that spatial patterns in haplotype distribution were absent and that neither similar nor rare haplotypes clustered geographically (Fig. 3). Such random associations of haplotypes with geographical location can arise due to many reasons. According to Gold and Richardson (1998), absence of spatial patterns in allele or haplotype distribution among geographical samples of a species are evidence for a single population with no barriers to gene flow. Further, populations can be driven by founder effects that arise whenever suitable refugia or new habitat patches are created, which are then colonized by a random selection of strains from regional sources (Van Gremberghe et al., 2011). Ubiquitous distributions with little biogeographic signature can also occur due to high dispersal ability of species or dispersal assisted by wind or by rafting in organisms with low vagility (Pfeiler and Markow, 2011). 
Table 2. Genetic indices for the tiger beetles of Sri Lanka

\begin{tabular}{|c|c|c|c|c|c|c|c|c|}
\hline \multirow[t]{2}{*}{ Species } & \multicolumn{5}{|c|}{ No. of } & \multirow{2}{*}{$\begin{array}{c}\text { Haplotype } \\
\text { Diversity (Hd) }\end{array}$} & \multirow{2}{*}{$\begin{array}{c}\text { Nucleotide } \\
\text { Diversity (Pi) }\end{array}$} & \multirow{2}{*}{$\begin{array}{c}\text { Tajima's D } \\
\text { Statistics }\end{array}$} \\
\hline & Populations & $\begin{array}{l}\text { Individuals } \\
\text { sequenced }\end{array}$ & $\begin{array}{l}\text { Polymorphic } \\
\text { sites }\end{array}$ & Haplotypes & $\begin{array}{c}\text { Singleton } \\
\text { Haplotypes }\end{array}$ & & & \\
\hline Lophyra catena & 05 & 13 & 06 & 06 & 03 & $0.7821 \pm 0.105$ & $0.00157 \pm 0.0003$ & $\begin{array}{l}-0.75444 \\
(p>0.1)\end{array}$ \\
\hline $\begin{array}{l}\text { Myriochila (Monelica) } \\
\text { fastidiosa }\end{array}$ & 03 & 08 & 42 & 08 & 08 & $1.0000 \pm 0.063$ & $0.01173 \pm 0.00212$ & $\begin{array}{l}-1.33374 \\
(p>0.1)\end{array}$ \\
\hline $\begin{array}{l}\text { Cylindera (Ifasina) } \\
\text { labioaenea }\end{array}$ & 09 & 18 & 61 & 17 & 16 & $0.9935 \pm 0.021$ & $0.00867 \pm 0.0004$ & $\begin{array}{l}-0.99840 \\
(p>0.1)\end{array}$ \\
\hline Calomera angulata & 11 & 24 & 13 & 11 & 09 & $0.7790 \pm 0.081$ & $0.00211 \pm 0.0004$ & $\begin{array}{l}-1.52307 \\
(p>0.1)\end{array}$ \\
\hline Hypaetha biramosa & 03 & 08 & 09 & 07 & 06 & $0.9643 \pm 0.077$ & $0.00222 \pm 0.00031$ & $\begin{array}{l}0.29283 \\
(p>0.1)\end{array}$ \\
\hline $\begin{array}{l}\text { Cylindera (Ifasina) } \\
\text { willeyi }\end{array}$ & 02 & 08 & 26 & 05 & 03 & $0.8570 \pm 0.108$ & $0.00673 \pm 0.00115$ & $\begin{array}{l}1.20582 \\
(p>0.1)\end{array}$ \\
\hline $\begin{array}{l}\text { Cylindera (Ifasina) } \\
\text { waterhousei }\end{array}$ & 02 & 07 & & 03 & 01 & $0.6667 \pm 0.160$ & $0.00131 \pm 0.00038$ & $\begin{array}{l}0.05645 \\
(p>0.1)\end{array}$ \\
\hline
\end{tabular}



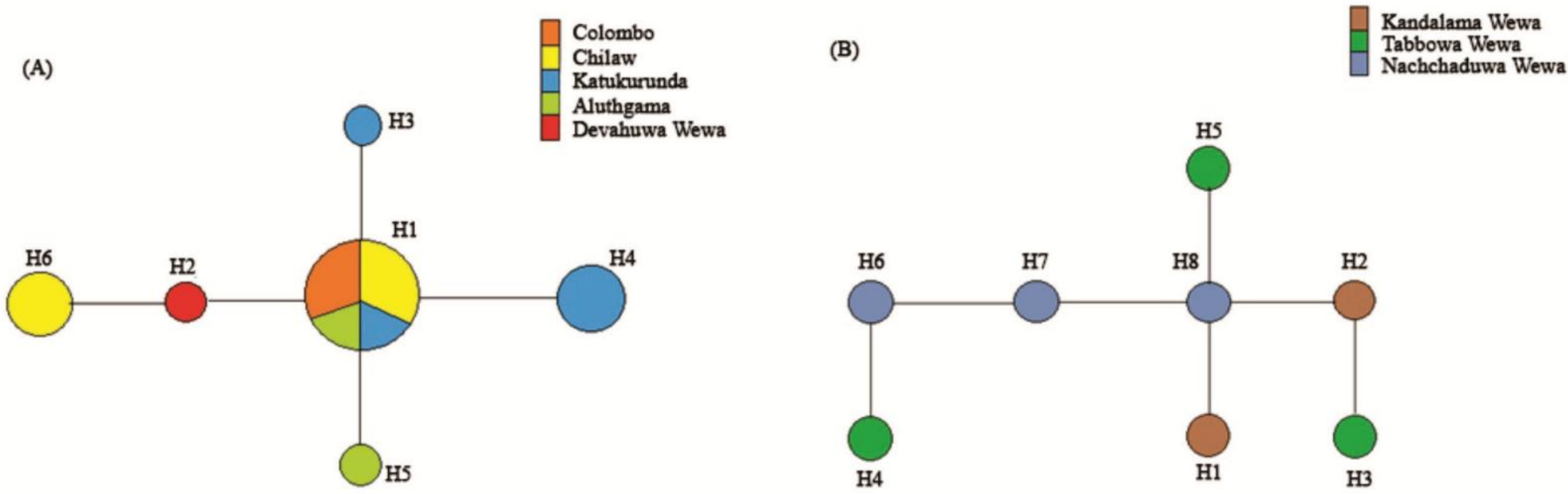

(C)

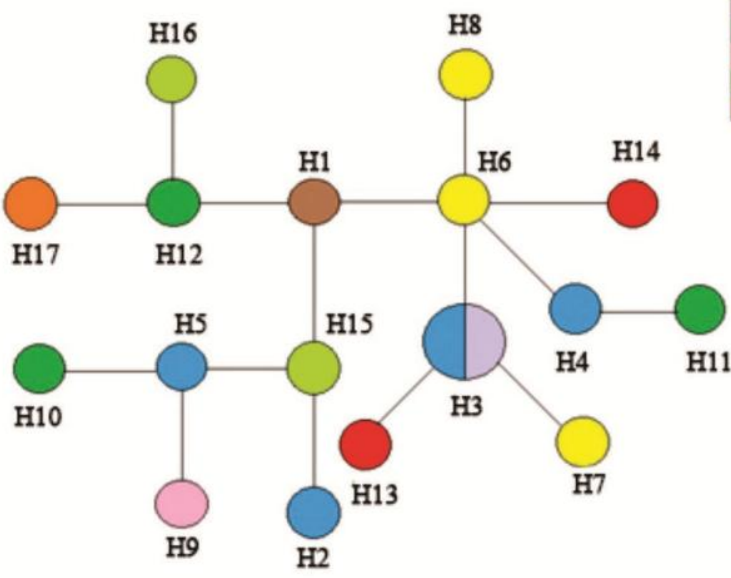

Puvakpitiya

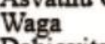

Dehiovita

(D)

Maha Oya, Dehiovita

Kirielamulla

Malwana

Kaduwela
Angoda

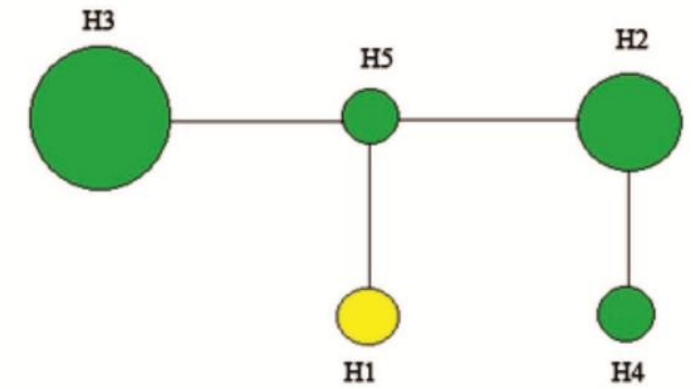

Handapangoda

Figure 3. Mitochondrial DNA networks for the tiger beetle species of Sri Lanka. (A) Lophyra catena (B) Monelica (Myriochila) fastidiosa (C) Cylindera (Ifasina) labioaenea (D) Cylindera (Ifasina) willeyi. The areas under circles are proportionatre to the number of samples sharing each haplotype. Different colours represent different geographical populations (see legends) 
(E)

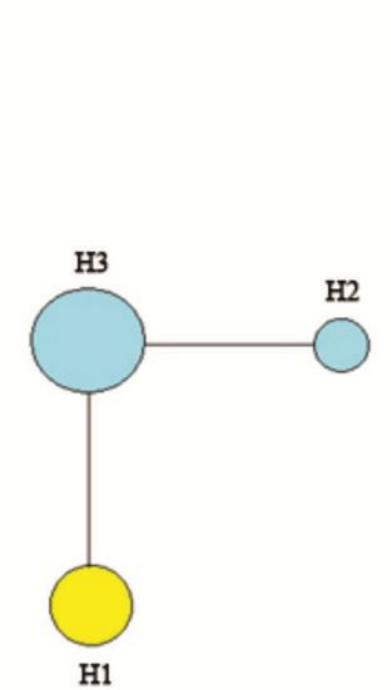

H1
(F)

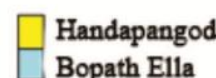

Bopath Ella

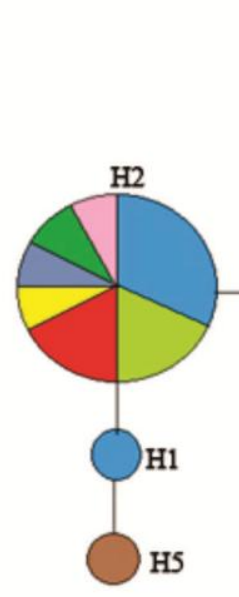

HS

(G)

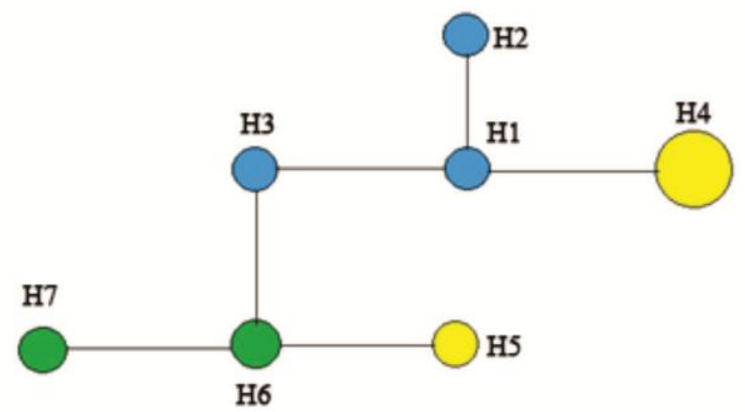

Kosgoda

Matara

Habaraduwa

Figure 3 contd. Mitochondrial DNA networks for the tiger beetle species of Sri Lanka. (E) Cylindera (Ifasina) waterhousei (F) Calomera angulata (G) Hypaetha biramosa. The areas of the circles are proportional to the number of samples sharing each haplotype. Different colours represent different geographical populations (see legends). 
Table 3. Tajima's D values for separate genes of tiger beetles with negative Tajima's D statistic for the combined gene sequences

\begin{tabular}{|c|c|c|c|c|c|}
\hline Species & Gene & Tajima's D (all) & Tajima's D (Syn) & Tajima's D (NonSyn) & $\begin{array}{l}\text { Tajima's D Ratio } \\
\text { (NonSyn/Syn) }\end{array}$ \\
\hline Lophyra (Lophyra) catena & $\begin{array}{c}\text { CO1 } \\
\text { CytB } \\
\text { 16SrRNA }\end{array}$ & $\begin{array}{l}-0.35040 \\
-0.82906 \\
-1.32167\end{array}$ & $\begin{array}{l}-0.27429 \\
-1.14915 \\
-1.12850\end{array}$ & $\begin{array}{l}-0.27429 \\
-0.47825 \\
-1.11391\end{array}$ & $\begin{array}{l}1.00000 \\
0.41618 \\
0.98707\end{array}$ \\
\hline $\begin{array}{l}\text { Myriochile (Monelica) } \\
\text { fastidiosa }\end{array}$ & $\begin{array}{c}\mathrm{CO} 1 \\
\text { CytB } \\
\text { 16SrRNA }\end{array}$ & $\begin{array}{l}-1.19544 \\
-1.48054 \\
-0.49212\end{array}$ & $\begin{array}{l}-1.23478 \\
-1.05482 \\
-1.23716\end{array}$ & $\begin{array}{l}-0.44794 \\
-1.45249 \\
-0.17257\end{array}$ & $\begin{array}{l}0.36277 \\
1.37701 \\
0.13949\end{array}$ \\
\hline $\begin{array}{l}\text { Cylindera (Ifasina) } \\
\text { labioaenea }\end{array}$ & $\begin{array}{c}\text { CO1 } \\
\text { CytB } \\
\text { 16SrRNA }\end{array}$ & $\begin{array}{l}-0.51679 \\
-0.50212 \\
-1.17557\end{array}$ & $\begin{array}{c}-0.43543 \\
\text { na } \\
0.91144\end{array}$ & $\begin{array}{l}-0.68954 \\
-0.50212 \\
-1.74333\end{array}$ & $\begin{array}{c}1.58360 \\
\text { na } \\
-1.91272\end{array}$ \\
\hline Calomera angulata & $\begin{array}{c}\text { CO1 } \\
\text { CytB } \\
\text { 16SrRNA }\end{array}$ & $\begin{array}{l}-1.16908 \\
-1.68244 \\
-0.58881\end{array}$ & $\begin{array}{l}-0.77044 \\
-1.15933 \\
-1.16467\end{array}$ & $\begin{array}{l}-1.51314 \\
-1.51378 \\
-0.15474\end{array}$ & $\begin{array}{l}1.96400 \\
1.30573 \\
0.13286\end{array}$ \\
\hline
\end{tabular}


When a population expands into or colonizes a new geographical area, genetic homogeneity could be created within the recently colonized area (Templeton et al., 1995). Furthermore, old haplotypes are expected to be geographically widespread than their derived, less-common relatives as young haplotypes have a reduced chance of being part of dispersal events (Fry and Zink, 1998). Therefore, the tiger beetle species of Sri Lanka maybe single populations consisting of subpopulations located in continuous habitats.

The tiger beetle species investigated in our study revealed high haplotype diversities and low nucleotide diversities (Table 2). The combination of high haplotype diversity and low nucleotide diversity, as observed in our data, can be a signature of a rapid population expansion from a small effective population size (de Jong et al., 2011). Tajima's D statistic can be used to determine the accuracy of the above suggestion. Tajima's D generates a negative value when there is an excess of low frequency polymorphisms than expected and suggests populations to be recently expanding or subjected to positive selection. Significantly negative values for Tajima's D calculated for synonymous sites, together with a Tajima's D ratio of less than 1.0 for non-synonymous sites/ synonymous sites indicates population expansion, while a ratio of more than 1.0 may favour positive selection. Tajima's D statistic generates a positive value when there are fewer than expected low frequency polymorphisms which results in population reduction, population subdivision, a recent bottleneck, migration or balancing selection (Schmidt and Pool, 2002; de Jong et al., 2011).

\section{Calomera angulato}

Calomera angulata consisted of 11 haplotypes of which 9 were singletons. The combination of high haplotype diversity with low nucleotide diversity, lack of phylogeographical structuring, high proportion of singleton haplotypes and negative value for Tajima's D statistic indicates the possibility of a recent population expansion for the species (Fig. 3F, Table 2).

Calomera angulata currently occupies one riverine and 9 reservoir habitats located in the NorthCentral, North-Western and Central provinces of the country (Dangalle et al., 2012a). However, Calomera angulata is considered as a coastal tiger beetle in Japan (Satoh and Hori, 2004, Satoh et al., 2004) and has been reported from riverine habitats of India (Wiesner, 1975; Ganeshaiah and Belavadi, 1986). The British Natural History Museum of London houses specimens of Calomera angulata collected from the coastal area of Yala National Park in the Southern province of Sri Lanka, and the collections at the National Museum of Colombo has specimens collected from the coasts of Eastern and Northern shores (Mannar, Pesalai and Talaimannar) of the country. The present study reveals that the coastal ecosystems of the country are mostly inhabited by Hypaetha biramosa. Therefore, it is possible that Calomera angulata may have occupied coastal habitats of the island previously and may have been displaced to the reservoir habitats by Hypaetha biramosa. Therefore, Calomera angulata of the reservoir habitats maybe a more recent radiation that has experienced recent population expansion. Eventhough, the overall negative values resulting from Tajima's D value for combined sequences, Tajima's D for separate genes, Tajima's D for synonymous sites justifies this possibility further analysis using nuclear genes would provide a more complete perspective.

Due to the similar climatic and soil conditions of the current habitats (Dangalle et al., 2012b), lack of major geographical barriers and close proximity of the locations to each other, Calomera angulata may occur as a single population of tiger beetles consisting of subpopulations with multiple haplotypes. Haplotype 2, which is geographically widespread can be considered as the basal haplotype from which the other haplotypes have arisen (Fig. 3F).

\section{Lophyra (Lophyra) catena, Myriochila (Monelica) fastidiosa, Cylindera (Ifasina) labioaenea}

Lophyra (Lophyra) catena was found in five locations of which four were located on the western coast of the country (Fig. 1 and Table 1). Haplotype 1 , which was distributed in these four locations can be considered as the basal haplotype of the species (Fig. 3A). However, a unique haplotype (haplotype 2) was found at Devahuwa wewa, a reservoir habitat in the central part of the country (Fig. 3A). Our data suggests that Lophyra (Lophyra) catena may be a tiger beetle population on the western coast of Sri Lanka that is expanding rapidly and exploiting more locations and other habitat types.

Lophyra (Lophyra) catena displayed a high haplotype diversity (Table 2), low nucleotide diversity (Table 2), lack of phylogeographical structuring (Fig. 3A), and a negative value for Tajima's D statistic and Tajima's D value for synonymous sites (Tables 2 and 3) that indicated the possibility of population expansion. However, Tajima's D value was not significantly negative and values calculated for synonymous sites of the separate genes, CO1, CytB, 16SrRNA, were also not significantly negative (Table 3 ). When considering the Tajima's D ratio between nonsynonymous and synonymous sites, a ratio less than 1.0 was revealed for $\mathrm{CytB}$ gene indicating 
population expansion. However, the ratio for $\mathrm{CO} 1$ gene was 1.0 and approximately 1.0 for $16 \mathrm{SrNA}$ (Table 3), suggesting the possibility of neutral evolution. Overall the negative values resulting from the tests indicate that there is an excess of rare mutations in the populations, which can imply recent population expansion. However, an analysis using neutral nuclear DNA markers could give a more complete perspective on the population structure of the species.

When considering Myriochila (Monelica) fastidiosa, the species consisted entirely of singleton haplotypes which were distributed in three reservoir habitats (Fig. 3B). This lack of phylogeographical structuring, high haplotype diversity, low nucleotide diversity (Table 2), negative values for Tajima's D statistic and Tajima's D value for synonymous sites and NonSyn / Syn Tajima's D ratios less than 1.0 (Tables 2 and 3 ) indicated the possibility of recent population expansion. However, similar to Lophyra (Lophyra) catena, Tajima's D values lacked significance and Tajima's D ratio for CytB was higher than 1.0 which was an indication that the sequences might be evolving under positive selection.

Cylindera (Ifasina) labioaenea also displayed high haplotype diversity, low nucleotide diversity (Table 2), lack of phylogeographical structuring (Fig. 3C) and a negative value for Tajima's D statistic (Table 2 ) that indicated the possibility of recent population expansion. However, contradictory values were obtained for Tajima's D for synonymous sites and Tajima's D ratio, when using different genes (Table 3 ), suggesting the need of further analysis using nuclear genes.

\section{Hypaetha biramosa}

Hypaetha biramosa was restricted entirely to the coastal habitats of the country and lacked phylogeographical structuring. The combination of high haplotype diversity with low nucleotide diversity indicated that the populations of the species were expanding. However, Tajima's D statistic was positive for the species and implied population reduction, subdivision, migration or a bottleneck effect. Coastal tiger beetle populations may frequently experience bottlenecks caused by natural disasters such as storms or tsunami (Satoh et al., 2004).

However, specimens of Hypaetha biramosa were collected in 2003, prior to the 2004 tsunami which affected these coastal areas of Sri Lanka. Therefore, we can assume that Hypaetha biramosa experienced a bottleneck effect due to storms or some other factors and expanded after the conditions became favourable.

\section{Cylindera (Ifasina) willeyi and Cylindera (Ifasina) waterhousei}

These are endemic tiger beetles restricted to the wet zone of Sri Lanka. These species displayed high haplotype diversity, low nucleotide diversity, lack of phylogeographic structure and a positive value for Tajima's D statistic that implied population reduction, subdivision, migration or a bottleneck effect prior to population expansion.

Cylindera (Ifasina) willeyi has been recorded from the Central Province of Sri Lanka and from Labugama in the Western Province (Horn, 1904; Fowler, 1912; Acciavatti and Pearson, 1989). Investigations of the present study confirms the absence of the species from it's previous localities, and shows it's presence from Maha Oya, Dehi Owita (Sabaragamuwa Province) and Handapangoda (Western Province) from which they had not been previously recorded. According to Dangalle et al. (2011a) human activities and development pressures on the previous habitats of Cylindera (Ifasina) willeyi has resulted a $99.5 \%$ decline in the distributional range of the species. Due to this Cylindera (Ifasina) willeyi may have migrated to the new habitats or may have experienced a bottle neck effect. The favourable climate and soil conditions of the currently occupied habitats (Dangalle et al., 2011a) may generate a population expansion.

Cylindera (Ifasina) waterhousei has been previously recorded from Labugama and Avissawella of the Western Province of Sri Lanka and Kitulgala and Karawanella of the Sabaragamuwa Province (Naviaux, 1984; Acciavatti and Pearson, 1989). Currently the species is absent from these locations and occupies Handapangoda of the Western Province and Bopath Ella of the Sabaragamuwa Province. The presence of other tiger beetle species, Cylindera (Ifasina) willeyi and Cylindera (Ifasina) labioaenea, in the previously recorded locations of Cylindera (Ifasina) waterhousei, that may compete for food, thermal resources, oviposition sites and larval resources, is a possible cause for Cylindera (Ifasina) waterhousei to have become locally displaced from its previous locations (Dangalle et al., 2011b). According to the present study Cylindera (Ifasina) waterhousei may have undergone migration and is experiencing population expansion in it's new locations.

Thus, our results did not indicate geographical population structure amongst the tiger beetle species of Sri Lanka. Genetic indices and Tajima's $\mathrm{D}$ test that we used to assess signatures of recent historical demographic events suggested recent population expansion for certain species and migration and bottleneck effects followed by 
population expansion for certain species. However, Tajima's D test was not significant and suggested that an analysis including additional neutral DNA markers could give a more complete perspective on the neutral population structure of the populations.

The tiger beetle species that were studied consisted of mtDNA haplotypes of which the majority were singletons. Recent reviews suggest that in tropical arthropod samples, $30 \%$ of all species are singletons with additional sampling helping little with eliminating rarity (Lim et al., 2011). In our study $53 \%$ of the tiger beetle specimens were singletons and the number of singleton haplotypes increased with the number of total haplotypes (Fig. $2)$. Therefore, existing and future techniques for tiger beetle sampling needs to be modified to accommodate how rare species can be discovered and treated.

\section{REFERENCES}

Acciavatti, R.E. and Pearson, D.L. (1989). The tiger beetle genus Cicindela (Coleoptera, Insecta) from the Indian subcontinent. Annals of Carnegie Museum 58(4): 77-355.

Bossuyt, F., Meegaskumbura, M., Beenaerts, N., Gower, D.J., Pethiyagoda, R., Roelants, K., Mannaert, A., Wilkinson, M., Bahir, M.M., Manamendra-Arachchi, K., Ng, P.K.L., Schneider, C.J., Oommen, O.V. and Milinkovitch, M.C. (2004). Local endemism within the Western Ghats-Sri Lanka biodiversity hotspot. Science 306: 479-481.

Cassola, F. and Pearson, D.L. (2000). Global patterns of tiger beetle species richness (Coleoptera: Cicindelidae) their use in conservation planning. Biological Conservation 95: 197-208.

Dammannagoda, S.T., Hurwood, D.A. and Mather, P.B. (2011). Genetic analysis reveals two stocks of skipjack tuna (Katsuwonus pelamis) in the northwestern Indian Ocean. Canadian Journal of Fisheries and Aquatic Sciences 68: 210-223.

Dangalle, C., Pallewatta, N. and Vogler, A. (2011a). The current occurrence, habitat and historical change in the distributional range of an endemic tiger beetle species Cicindela (Ifasina) willeyi Horn (Coleoptera: Cicindelidae) of Sri Lanka. Journal of Threatened Taxa 3(2): 14931505.

Dangalle, C., Pallewatta, N. and Vogler, A. (2011b). The occurrence of the endemic tiger beetle Cicindela (Ifasina) waterhousei in Bopath Ella, Ratnapura, Sri Lanka. Journal of the National Science Foundation of Sri Lanka 39(2): 163-168.

Dangalle, C., Pallewatta, N. and Vogler, A. (2012b). Tiger beetles (Coleoptera: Cicindelidae) of ancient reservoir ecosystems of Sri Lanka. Journal of Threatened Taxa 4(4): 2490-2498.

Dangalle, C.D., Pallewatta, N. and Vogler, A.P. (2012a). Habitat specificity of tiger beetle species (Coleoptera, Cicindelidae) of Sri Lanka. Cicindela 44(1): 1-32.

de Jong, M.A., Wahlberg, N., van Eijk, M., Brakefield, P.M. and Zwaan, B.J. (2011). Mitochondrial DNA signature for range-wide populations of Bicyclus anynana suggests a rapid expansion from recent refugia. PLoS ONE 6(6): 1-5.

Delorme, M., Dubois, A., Kosuch, J. and Vences, M. (2004). Molecular phylogenetic relationships of Lankanectes corrugates from Sri Lanka: endemism of South Asian frogs and the concept of monophyly in phylogenetic studies. Alytes 22(1-2): 53-64.

Fernando, P., Pfrender, M.E., Encalada, S.E. and Lande, R. (2000). Mitochondrial DNA variation, phylogeography and population structure of the Asian elephant. Heredity 84: 362-372.

Fowler, W.W. (1912). Fauna of British India including Ceylon and Burma \{Coleoptera General Introduction and Cicindelidae and Paussidae\}. Today and Tomorrow's Printers and Publishers, New Delhi.

Fry, A.J. and Zink, R.M. (1998). Geographic analysis of nucleotide diversity and song sparrow (Aves: Emberizidae) population history. Molecular Ecology 7: 1303-1313.

Ganeshaiah, K.N. and Belavadi, V.V. (1986). Habitat segregation in four species of adult tiger beetles (Coleoptera: Cicindelidae). Ecological Entomology 11: 147-154.

Gold, J.R. and Richardson, L.R. (1998). Genetic homogeneity among geographic samples of snappers and groupers: evidence of continuous geneflow? Proceedings of the 50 th Gulf and Caribbean Fisheries Institute 709-726.

Hemingway, J., Hawkes, N., Prapanthadara, L., Jayawardenal, K.G.I. and Ranson, H. (1998). The role of gene splicing, gene amplification and regulation in mosquito insecticide resistance. Philosophical Transactions of the Royal Society of London 353: 1695-1699.

Hewitt, G.M. (2004). The structure of biodiversity - insights from molecular phylogeography. Frontiers in Zoology 1(4): 1-16.

Horn, W. (1904). The Cicindelidae of Ceylon. Spolia Zeylanica 2(5): 30-45.

Lim, G.S., Balke, M. and Meier, R. (2011). Determining species boundaries in a world full of rarity: singletons, species delimitation methods. Systematic Biology 60: 1-5.

Lorenz, W. (1998). Systematic list of extant ground beetles of the world (Insecta Coleoptera 
"Geoadephaga": Trachypachidae and Carabidae incl. Paussinae, Cicindelinae, Rhysodinae). Tutzing, Germany, 490pp.

Naviaux, R. (1984). Coleoptera, Cicindelidae. Les Cicindelés de Sri Lanka. Revue Scientifique Du Bourbonnais pp 57-80.

Nguyen, T.T.T., Na-Nakorn, U., Sukmanomon, S. and ZiMing, C. (2008). A study on phylogeny and biogeography of mahseer species (Pisces: Cyprinidae) using sequences of three mitochondrial DNA gene regions. Molecular Phylogenetics and Evolution 48: 1223-1231.

Pethiyagoda, R. (2005). Exploring Sri Lanka's biodiversity. The Raffles Bulletin of Zoology 12: 1-4.

Pfeiler, E. and Markow, T.A. (2011). Phylogeography of the cactophilic Drosophila and other arthropods associated with cactus necroses in the Sonoran desert. Insects 2: 218231.

Rozas, J., Sánchez-delbarrio, J.C., Messeguer, X. and Rozas, R. (2003). DnaSP 4.50, DNA polymorphism analyses by the coalescent and other methods. Bioinformatics 19: 2496-2497.

Samaraweewa, M., Himali, S.M.C., Zeng, S.C., Jianlin, H. and Silva, P. (2011). Development of molecular tools to differentiate Sri Lankan wild boar (Sus scrofa affinis) meat from exotic and village pig (Sus scrofa domestica) meat. Tropical Agricultural Research 23(1): 11-20.

Satoh, A. and Hori, M. (2004). Interpopulation differences in the mandible size of the coastal tiger beetle Lophyridia angulata associated with different sympatric species. Entomological Science 7: 211-217.

Satoh, A., Sota, T., Ueda, T., Enokido, Y., Paiks, J.C. and Hori, M. (2004). Evolutionary history of coastal tiger beetles in Japan based on a comparative phylogeography of four species. Molecular Ecology 13: 3057-3069.

Schmidt, D. and Pool, J. (2002) The effect of population history on the distribution of the Tajima's D statistic. < URL: http://www.cam. cornell.edu/deena/TajimasD.pdf $>17$ May 2002.

Silva, P., Guan, X., Ho-Shing, O., Jones, J., Xu, J., Hui, D., Notter, D. and Smith, E. (2009). Mitochondrial DNA-based analysis of genetic variation and relatedness among Sri Lankan indigenous chickens and the Ceylon Junglefowl (Gallus lafayetti). Animal Genetics 40(1): 1-9.

Surendran, S.N., Hawkes, N.J., Steven, A., Hemingway, J. and Ramasamy, R. (2006). Molecular studies of Anopheles culicifacies (Diptera: Culicidae) in Sri Lanka: Sibling species B and E show sequence identity at multiple loci. European Journal of Entomology 103: 233-237.

Templeton, A.R., Routman, E. and Phillips, C.A. (1995). Separating population structure from population history: A cladistic analysis of the geographical distribution of mitochondrial DNA haplotypes in the tiger salamander, Ambystoma tigrinum. Genetics 140: 767-782.

Tennent, J.E. (1860). Ceylon: An account of the island physical, historical and topographical with notices of its natural history, antiquities and productions. Longman and Roberts, London.

Van Gremberghe, I.V., Leliaert, F., Mergeay, J., Vanormelingen, P., Van der Gucht, K. et al. (2011). Lack of phylogeographic structure in the freshwater cyanobacterium Microcystis aeruginosa suggests global dispersal. PLoS ONE 6(5), 1-12.

Wiesner, J. (1975). Notes on Cicindelidae of India and Sri Lanka. Cicindela 7(4), 61-70.

Wijesekara, A. and Wijesinghe, D.P. (2003). History of insect collection and a review of insect diversity in Sri Lanka. Ceylon Journal of Science (Biological Science) 31: 43-59. 
Appendix 1. Genbank accession numbers for the tiger beetle species of Sri Lanka

\begin{tabular}{|c|c|c|c|c|}
\hline Species & $\begin{array}{l}\text { Number } \\
\text { of } \\
\text { specimens } \\
\text { sequenced }\end{array}$ & $\begin{array}{l}\text { Accession numbers } \\
\text { for CO1 }\end{array}$ & $\begin{array}{l}\text { Accession numbers } \\
\text { for CytB }\end{array}$ & $\begin{array}{c}\text { Accession } \\
\text { numbers for } \\
\text { 16SrRNA }\end{array}$ \\
\hline Hypaetha biramosa & 08 & $\begin{array}{l}\text { JX051215-JX051222 } \\
(\mathrm{N}=08)\end{array}$ & $\begin{array}{l}\text { JX081550-JX051557 } \\
(\mathrm{N}=08)\end{array}$ & $\begin{array}{l}\text { JX081558- } \\
\text { JX051565 }(\mathrm{N}=08)\end{array}$ \\
\hline $\begin{array}{l}\text { Myriochila } \\
\text { (Monelica) fastidiosa }\end{array}$ & 08 & $\begin{array}{l}J X 081566-J X 081573 \\
(\mathrm{~N}=08)\end{array}$ & $\begin{array}{l}\text { JX081574-JX081581 } \\
(\mathrm{N}=08)\end{array}$ & $\begin{array}{l}\text { JX102522- } \\
\text { JX102528 }(\mathrm{N}=07)\end{array}$ \\
\hline $\begin{array}{l}\text { Lophyra (Lophyra) } \\
\text { catena }\end{array}$ & 13 & $\begin{array}{l}\text { JX102529-JX102541 } \\
(\mathrm{N}=13)\end{array}$ & $\begin{array}{l}J X 112270-J X 112282 \\
(\mathrm{~N}=13)\end{array}$ & $\begin{array}{l}\text { JX112283- } \\
\text { JX112293 }(\mathrm{N}=11)\end{array}$ \\
\hline $\begin{array}{l}\text { Cylindera } \quad \text { (Ifasina) } \\
\text { labioaenea }\end{array}$ & 18 & $\begin{array}{l}J X 129746-J X 129763 \\
(N=18)\end{array}$ & $\begin{array}{l}\text { JX129764-JX129781 } \\
(\mathrm{N}=18)\end{array}$ & $\begin{array}{l}\text { JX129782- } \\
\text { JX129799 }(\mathrm{N}=18)\end{array}$ \\
\hline Calomera angulata & 26 & $\begin{array}{l}J X 163134-J X 163159 \\
(\mathrm{~N}=26)\end{array}$ & $\begin{array}{l}\text { JX163160-JX163183 } \\
(\mathrm{N}=24)\end{array}$ & $\begin{array}{l}\text { JX182744- } \\
\text { JX182761 }(\mathrm{N}=18)\end{array}$ \\
\hline $\begin{array}{l}\text { Cylindera (Ifasina) } \\
\text { willeyi }\end{array}$ & 08 & $\begin{array}{l}J X 182762-J X 182769 \\
(\mathrm{~N}=08)\end{array}$ & $\begin{array}{l}\text { JX185682-JX185689 } \\
(\mathrm{N}=08)\end{array}$ & $\begin{array}{l}\text { JX193714- } \\
\text { JX193721 }(\mathrm{N}=08)\end{array}$ \\
\hline $\begin{array}{l}\text { Cylindera (Ifasina) } \\
\text { waterhousei }\end{array}$ & 07 & $\begin{array}{l}\text { JX196694-JX196700 } \\
(\mathrm{N}=07)\end{array}$ & $\begin{array}{l}J X 220518-J X 220524 \\
(N=07)\end{array}$ & $\begin{array}{l}\text { JX220525- } \\
\text { JX220531 (N=07) }\end{array}$ \\
\hline $\begin{array}{l}\text { Cylindera (Oligoma) } \\
\text { lacunose }\end{array}$ & 01 & $\mathrm{JX} 220533(\mathrm{~N}=01)$ & $\mathrm{JX} 220534(\mathrm{~N}=01)$ & $\mathrm{JX} 220532(\mathrm{~N}=01)$ \\
\hline $\begin{array}{l}\text { Cylindera (Oligoma) } \\
\text { paradoxa }\end{array}$ & 04 & $\begin{array}{l}J X 258128-J X 258131 \\
(\mathrm{~N}=04)\end{array}$ & $\begin{array}{l}J X 286504-J X 286507 \\
(\mathrm{~N}=04)\end{array}$ & $\begin{array}{l}\text { JX286508- } \\
\text { JX286511 }(\mathrm{N}=04)\end{array}$ \\
\hline Calomera cardoni & 03 & $\begin{array}{l}\text { JX294422-JX294424 } \\
(\mathrm{N}=03)\end{array}$ & $\begin{array}{l}J X 294425-J X 294426 \\
(N=02)\end{array}$ & $\begin{array}{l}\text { JX286512- } \\
\text { JX286514 }(\mathrm{N}=03)\end{array}$ \\
\hline
\end{tabular}

Number of specimens from which sequences were successfully obtained are given as "N" 
Appendix 2. Aligned 100 base pair region of mitochondrial DNA sequences of tiger beetle species

Calomera angulata

Mahakanadar H10 AATTAAAATTTTCTCATGACTTGCTACCCTTCATGGATCACAAATTTCCTATAGTCCCTCACTATTATGAGCCTTAGGATTTGTATTTTTATTCACAG Mahakanadara H4 AATTAAAATTTTCTCATGACTTGCTACCCTTCATGGATCACAAATTTCCTATAGTCCCTCATTATTATGAGCCTTAGGATTTGTATTTTTATTCACAGT Mahakanadara Thisa H1 Thisa H2 Thisa H2 Thisa $\mathrm{H} 2$ Thisa $\mathrm{H} 3$ Parakrama H4 Parakrama H2 Parakrama H2 Devahuwa $\mathrm{H} 6$ Devahuwa $\mathrm{H} 2$ Devahuwa H2 Batalagoda $\mathrm{H} 7$ Batalagoda H2 Batalagoda H4 Tabbowa H2 Tabbowa H8

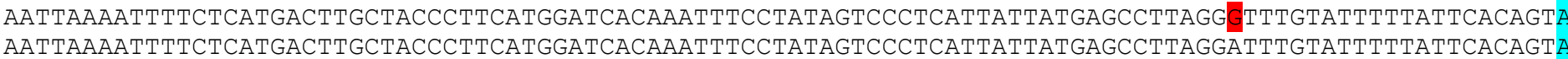
AATTAAAATTTTCTCATGACTTGCTACCCTTCATGGATCACAAATTTCCTATAGTCCCTCATTATTATGAGCCTTAGGATTTGTATTTTTATTCACAGTA AATTAAAATTTTCTCATGACTTGCTACCCTTCATGGATCACAAATTTCCTATAGTCCCTCATTATTATGAGCCTTAGGATTTGTATTTTTATTCACAGTA AATTAAAATTTTCTCATGACTTGCTACCCTTCATGGATCACAAATTTCCTATAGTCCCTCACTATTATGAGCCTTAGGATTTGTATTTTTATTCACAGT AATTAAAATTTTCTCATGACTTGCTACCCTTCATGGATCACAAATTTCCTATAGTCCCTCATTATTATGAGCCTTAGGATTTGTATTTTTATTCACAGT AATTAAAATTTTCTCATGACTTGCTACCCTTCATGGATCACAAATTTCCTATAGTCCCTCATTATTATGAGCCTTAGGATTTGTATTTTTATTCACAGTA AATTAAAATTTTCTCATGACTTGCTACCCTTCATGGATCACAAATTTCCTATAGTCCCTCATTATTATGAGCCTTAGGATTTGTATTTTTATTCACAGTA AATTAAAATTTTCTCATGACTTGCTACCCTTCATGGATCACAAATTTCCTATAGCCCCTCACTATTATGAGCCTTAGGATTTGTATTTTTATTCACAGT AATTAAAATTTTCTCATGACTTGCTACCCTTCATGGATCACAAATTTCCTATAGTCCCTCATTATTATGAGCCTTAGGATTTGTATTTTTATTCACAGTA AATTAAAATTTTCTCATGACTTGCTACCCTTCATGGATCACAAATTTCCTATAGTCCCTCATTATTATGAGCCTTAGGATTTGTATTTTTATTCACAGTA TTTTCTCATGACTTGCTACCCTTCATGGATCACAAATTTCCTATAGTCCCTCATTATTATGAGCCTTAGGATTTGTATTTTTATTCACAGT GGGTGGACT AATTAAAATTTTCTCATGACTTGCTACCCTTCATGGATCACAAATTTCCTATAGTCCCTCATTATTATGAGCCTTAGGATTTGTATTTTTATTCACAGTA AATTAAAATTTCTCATGACTTGCTACCCTTCATGGATCACAAATTTCCTATAGTCCCTCATTATTATGAGCCTTAGGATTTGTATTTTTATTCACAGT AATTAAAATTTTCTCATGACTTGCTACCCTTCATGGATCACAAATTTCCTATAGTCCCTCATTATTATGAGCCTTAGGATTTGTATTTTTATTCACAGT TTTTCTCATGACTTGCTACCCTTCATGGATCACAAATTTCCTATAGTCCCTCATTATTATGAGCCTTAGGATTTGTATTTTTATTCACAGTAGGTGGACT Nachchaduwa H2 AATTAAAATTTTCTCATGACTTGCTACCCTTCATGGATCACAAATTTCCTATAGTCCCTCATTATTATGAGCCTTAGGATTTGTATTTTTATTCACAGTA Kandalama H5 AATTAAAATTTTCTCATGACTTGCTACCCTTCATGGATCACAAATTTCCTATAGTCCCTCATTATTATGAGCCTTAGGATTTGTATTTTTATTCACAGTA Kandalama H4 AATTAAAATTTTCTCATGACTTGCTACCCTTCATGGATCACAAATTTCCTATAGTCCCTCATTATTATGAGCCTTAGGATTTGTATTTTTATTCACAGT Ma Oya H9 KalaWewa H11

\section{AATTAAAATTTTCTCATGACTTGCTACCCTTCATGGATCACAAATTTCCCATAGTCCCTCATTATTATGAGCCTTAGGATTTGTATTTTTATTCACAGT}

\section{Cylindera (Ifasina) waterhousei}

Handapan H1 ATTTTTTACCTTCCACTTTATCCTACCATTCATTGTTACTGCAATAGTACTAATTCACCTACTATTTTTACATCAAACTGGATCTAACAATCCATTAGGAA 100 bP Handapan $\mathrm{H} 1$

ATTTTTTACCTTCCACTTTATCCTACCATTCATTGTTACTGCAATAGTACTAATTCACCTACTATTTTTACATCAAACTGGATCTAACAATCCATTAGGA Bopath Ella H2 GTTTTTTACCTTCCACTTTATCCTACCGTTCATTGTTACTGCAATAGTACTAATTCACCTGCTATTTTTACATCAAACTGGATCTAACAATCCATTAGGAA Bopath Ella H2 GTTTTTTACCTTCCACTTTATCCTACCATTCATTGTTACTGCAATAGTACTAATTCACCTGCTATTTTTACATCAAACTGGATCTAACAATCCATTAGGAA Bopath Ella H3 GTTTTTTACCTTCCACTTTATCCTACCATTCATTGTTACTGCAATAGTACTAATTCACCTGCTATTTTTACATCAAACTGGATCTAACAATCCATTAGGAA Bopath Ella H3 GTTTTTTACCTTCCACTTTATCCTACCATTCATTGTTACTGCAATAGTACTAATTCACCTGCTATTTTTACATCAAACTGGATCTAACAATCCATTAGGAA Bopath Ella H3 GTTTTTTACCTTCCACTTTATCCTACCATTCATTGTTACTGCAATAGTACTAATTCACCTGCTATTTTTACATCAAACTGGATCTAACAATCCATTAGGAA 
Puvakpitiya H1 TTTGGAATAATTCTCATATTATTAGCCAAGAAAGAGGAAAAAAGGAACTTTTGGATCTCTAGGAATAATTTATGCTATACTAGCAATTGGCTTATTAg 100 bP Asvathu Oya H2 TTGGAATAATTCTCATATTATTAGTCAAGAAAGAGGAAAAAAGAAACTTTTGGATCTCTAGGATAATCTATGCTATACTAGCAATTGGCTTATTAGG Asvathu Oya H3 TTTGGAATAATTTCTCATATTATTAGCCAAGAAAGAGGGAAAAAGGAAACTTTTGGATCTCTAGGAATAATTTATGCTATACTAGCAATTGGCTTATTAG Asvathu Oya H4 TTTGGAATAATTTCTCATATTATTAGTCAAGAAAGAGGGAAAAAGGAAACTTTTGGATCTCTAGGAATAATTTATGCTATACTAGCAATTGGCTTATTAG Asvathu Oya H5 AATAATTTCTCATATTATTAGTCAAGAAAGAGGAAAAAAGGAAACTTTTGGATCTCTAGGAATAATTTATGCTATACTAGCAATTGGCTTATTAGGATTT Dehi Ovita H8 TTtGGAATAATTTCTCATATTATTAGCCAAGAAAGAGGAAAAAAGGAAACTTTTGGATCTCTAGGAATAATTTATGCTATACTAGCAATTGGCTTATTAG Dehi Ovita H7 TtTGGAATAATTTCTCATATTATTAGCCAAGAAAGAGGGAAAAAGGAAACTTTTGGATCTCTAGGAATAATTTATGCTATACTAGCAATTGGCTTATTAG

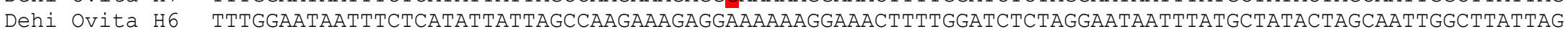
Seethavaka H9 AATAATTTCTCATATTATTAGTCAAGAAAGAGGGAAAAAGGAACTTTTGGATCTCTAGGAATAATTTATGCTATACTAGCAATTGGCTTATTAGGATTT Waga H3 Kiriela H10 Kiriela H12 Malwana H11 Malwana H13 Malwana H14 Kaduwela H16 Kaduwela H15 Angoda H17 TTTGGAATAATTTCTCATATATTAGCCAAGAAAGAGGGAAAAGGAAACTTTGGATCTCTAGGAATAATTTATGCTATACTAGCAATTGGCTTATTAG AATAATTTCTCATATTATTAGCCAAGAAAGAGGGAAAAAGGAAACTTTTGGATCTCTAGGAATAATTTATGCTATACTAGCAATTGGCTTATTAGGATTT TTTGGAATAATTTCTCATATTATTAGTCAAGAAAGAGGGAAAAAGGAAACTTTTGGATCTCTAGGAATAATTTATGCTATACTAGCAATTGGCTTATTAG TTTGGAATAATTTCTCATATTATTAGTCAAGAAAGAGGGAAAAAGGAAACTTTTGGATCTCTAGGAATAATTTATGCTATACTAGCAATTGGCTTATTAG TTTGGAATAATTCTCATATTATTAGTCAAGAAA GA GGAAAAAGGAAACTTTTGGATCTCTAGGAATAATTTATGCTATACTAGCAATTGGCTTATTAG TTTGGAATAATTTCTCATATTATTAGCCAAGAAAGAGGAAAAAAGGAAACTTTTGGATCTCTAGGAATAATTTATGCTATACTAGCAATTGGCTTATTAG TTTGGAATAATTTCTCATATTATTAGCCAAGAAAGAGGGAAAAAGGAAACTTTTGGATCTCTAGGAATAATTTATGCTATACTAGCAATTGGCTTATTAG TAATTTCTCATATTATTAGCCAAGAAAGAGGGAAAAAGGAAACTTTTGGATCTCTAGGAATAATTTATGCTATACTAGCAATTGGCTTATTAGGATTTGT AAAAGAAACTTTTGGACTCTAGGAATAATTATGCTATACTAGCAATTGGCTTATTAGGATTTGTAGTATGAGCTCACCACATATTTACTGTAGGAAT

Cylindera (Ifasina) willeyi

Handapan $\mathrm{H} 1$ Dehi Ovita

Dehi Ovita H3 Dehi Ovita H2 Dehi Ovita H2 Dehi Ovita H3 Dehi Ovita H3 Dehi Ovita 44
TCCCATTCCATCCCTATTTTACTTTTAAGGACATCATAGGATTCATTATTCTTATAATAATACTAACTCTATTGACTCTCTTAAATCCCTACTACCTTGG GCATCAAACTGGGTCTAACAATCCATTAGGGATAAATAGTAATATTGATAAAATCCCATTCCATCCCTATTTTACTTTTAAGGACATCATAGGATTCATT TACATCAAACTGGGTCTAACAATCCATTAGGAATAAATAGTAATATTGATAAAATCCCATTCCATCCCTATTTTACTTTTAAGGACATCATAGGATTCATT GCATCAAACTGGGTCTAACAATCCATTAGGGATAAATAGTAATATTGATAAAATCCCATTCCATCCCTATTTTACTTTTAAGGACATCATAGGATTCATT GATCAAACTGGGTCTAACAATCCATTAGGGATAAATAGTAATATTGATAAAATCCCATTCCATCCCTATTTTACTTTTAAGGACATCATAGGATTCATT TACATCAAACTGGGTCTAACAATCCATTAGGAATAAATAGTAATATTGATAAAATCCCATTCCATCCCTATTTTACTTTTAAGGACATCATAGGATTCATT

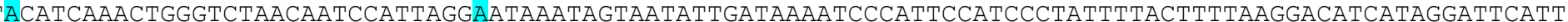
ACATCAAACTGGGTCTAACAATCCATTAGGAATAAATAGTAATATTGATAAAATCCCATTCCATCCCTATTTTACTTTTAAGGACATCATAGGATTCATT 
Kosgoda $\mathrm{H} 1$ Kosgoda H2 Kosgoda H3 Matara $\mathrm{H} 4$ Matara $\mathrm{H} 4$ Matara $\mathrm{H} 5$ Habarad $\mathrm{H} 6$ Habarad $\mathrm{H}$

\section{Lophyra (Lophyra) catena}

Colombo H1 GGATTTGCTGTCGACAATGCCACACTAACACGATTTTTTACATTCCATTTTATTTTACCCTTCATTGTAGCAGCAATAGTACTAATTCACCTCCTATTCCT 100 bP Colombo H1 GGATTTGCTGTCGACAATGCCACACTAACACGATTTTTTACATTCCATTTTATTTTACCCTTCATTGTAGCAGCAATAGTACTAATTCACCTCCTATTCCT Devahuwa H2 GGATTTGCTGTTGACAATGCCACACTAACACGATTTTTTACATTCCATTTTATTTTACCCTTCATTGTAGCAGCAATAGTACTAATTCACCTCCTATTCCT Katukurun H3 GGATTTGCTGTCGACAATGCCACACTAACACGATTTTTTATATTCCATTTTATTTTACCCTTCATTGTAGCAGCAATAGTACTAATTCACCTCCTATTCCT Katukurun H4 GGATTTGCTGTCGACAATGCCACACTAACACGATTTTTTACATTCCATTTTATTTTACCCTTCATTGTAGCAGCAATAGTACTAATTCACCTCCTATTCCT Katukurun H1 GGATTTGCTGTCGACAATGCCACACTAACACGATTTTTTACATTCCATTTTATTTTACCCTTCATTGTAGCAGCAATAGTACTAATTCACCTCCTATTCCT Katukurun H4 GGATTTGCTGTCGACAATGCCACACTAACACGATTTTTTACATTCCATTTTATTTTACCCTTCATTGTAGCAGCAATAGTACTAATTCACCTCCTATTCCT Aluthgama H5 GGATTTGCTGTCGACAATGCCACACTAACGCGATTTTTTACATTCCATTTTATTTTACCCTTCATTGTAGCAGCAATAGTACTAATTCACCTCCTATTCC Aluthgama H1 GGATTTGCTGTCGACAATGCCACACTAACACGATTTTTTACATTCCATTTTATTTTACCCTTCATTGTAGCAGCAATAGTACTAATTCACCTCCTATTCCI Hal awatha H1 GGATTTGCTGTCGACAATGCCACACTAACACGATTTTTTACATTCCATTTTATTTTACCCTTCATTGTAGCAGCAATAGTACTAATTCACCTCCTATTCC Hal awatha H6 GGATTTGCTGTTGACAATGCCACACTAACACGATTTTTTACATTCCATTTTATTTTACCCTTCATTGTAGCAGCAATAGTACTAATTCACCTCCTATTCCT Halawatha H6 GGATTTGCTGTTGACAATGCCACACTAACACGATTTTTTACATTCCATTTTATTTTACCCTTCATTGTAGCAGCAATAGTACTAATTCACCTCCTATTCCT Halawatha H1 GGATTTGCTGTCGACAATGCCACACTAACACGATTTTTTACATTCCATTTTATTTTACCCTTCATTGTAGCAGCAATAGTACTAATTCACCTCCTATTCCT

\section{Myriochila (Monelica) fastidiosa}

Kandalama $\mathrm{H} 1$ Kandalama H2 Tabbowa H5

Tabbowa $\mathrm{H} 4$

Tabbowa H3

Nachchaduwa $\mathrm{H} 6$ Nachchaduwa H7 Nachchaduwa H8
CAGCTATCCCATATGTCGGAACCATGCTTGTCCAATGAGTCTG CAGCTATCCCATATGTCGGAACCATGCTTGTCCAATGAGTTTG CAGCTATCCCATATGTCGGAACCATGCTTGTCCAATGAGTTTG CAGCTATCCCATATGTCGGAACCATGCTTGTCCAATGAGTTTG

CAGCTATCCCATATGTTGGAACCATGCTTGTCCAATGAGTTTG

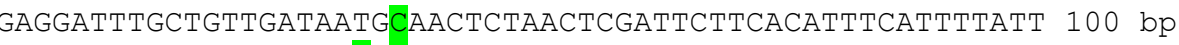
GAGGATTTGCTGTTGATAACG GAGGATTTGCTGTTGATAA GAGGATTTGCTGTCGATAA GCAACTCTAACTCGATTCTTCACATTTCATTTTATT AACTCTAACTCGATTCTTCACATTTCATTTTATT AAACTCTAACTCGATTCTTCACATTTCATTTCATT GGAGGATTTGCTGTTGATAACGCAACTCTAACTCGATTCTTCACATTTCATTTTATT 